\title{
Geotechnical Properties of Problem Clay Stabilized with Crumb Rubber Powder
}

\author{
Purushotham G. Sarvade and Prashant R Shet
}

\begin{abstract}
Mangalore tiles are a type of tiles native to the city of Mangalore, India. These are widely used as a roofing material throughout India, especially in coastal regions to drain off the rain water. But in recent times the tile industries have been facing problems due to non availability of good clay. The available clay for the manufacture of tile is lacking in desirable properties. The properties of the available clay have to be improved by some methods. It is proposed to use Crumb Rubber Powder (CRP) which is made from scrap and old tires is used as an additive to improve problem clay and study the effect of CRP on strength of problem clay after stabilization. The main objective of the investigation is to evaluate optimum CRP for stabilization of the clay from the view point of plasticity and strength characteristics. This paper reports the findings of experimental studies with regard to geotechnical properties (particle size, specific gravity, compaction characteristics, and unconfined compression strength (UCS) of both problem clay and stabilized clay, and to evaluate their suitability in tile industry. Also an investigation was carried out to study the effect of cement and lime on CRP stabilized clay. The investigation revealed that $C R P$ altered the engineering properties of problem clay and 5\% CRP has been chosen as the optimum CRP to get desired properties.
\end{abstract}

The unconfined compressive strength was increased when the optimum mix (problem clay+5\% of CRP) was blended with cement and lime.

Keywords--- Crumb Rubber Powder, Mangalore Tiles, Stabilisation, Unconfined Compressive Strength

\section{INTRODUCTION}

$\mathrm{T}$ HE origin of the clay roof tiles can be traced from many centuries ago, in China \& Middle East and is still in use all around the world. From these regions the use of clay roof tiles spread throughout Asia and Europe. Not only the ancient Egyptians and Babylonians, but also the Greeks and Romans roofed their dwellings with clay tiles, adaptations of their practice continue in Europe to the present. European settlers

Purushotham G. Sarvade, Associate Professor, Department of Civil Engineering, Manipal Institute of Technology, Manipal University, Manipal576104, Karnataka.India. E-mail:pgsarvade@gmail.com

Prashant R Shet, P.G Student in Structural Engineering, Department of Civil Engineering, Manipal Institute of Technology, Manipal University, Manipal-576104, Karnataka,India.E-mail:shetnishant@ymail.com brought this roofing tradition to America where it was established in many places by the $17^{\text {th }}$ century.

A German missionary set up the first tile factory at Mangalore, India in 1860. Abundant deposits of clay, plenty of firewood from the Western Ghats and the cheap skilled labour helped the industries to flourish in Mangalore. By the 1900s there were around 25 tile factories situated in and Mangalore. By 1994 around 75 tile factories were present in Mangalore. Mangalore tiles were the only tiles to be recommended for Government buildings in India during the British regime. But in recent times the tile industries have been facing problems due to non availability of good clay. The available clay for the manufacture of tile is lacking in desirable properties. In such cases, the properties of the soil have to be improved by some methods. Soil stabilization is the collective term used to denote any physical, chemical or biological method or any combination of such methods employed to improve certain properties of natural soil to make it serve adequately for an intended engineering purpose.

According to Ashmawy et al., [1], waste materials such as scrap tires, ash, and wastewater sludge, offers a viable alternative from economical, technical and environmental stand points. Thus scrap tires, ash, and wastewater sludge showed good potential for stabilizing soils by blending. Ho[2], investigated how to incorporate a 'green' element in the existing stabilization technique, rubber chips derived from waste rubber tyres were used together with cement to stabilized kaolin in the laboratory, exploring the feasibility of the innovative stabilizer. Rubber chips alone did not contribute much to strength improvement of the kaolin specimens but are able to increase the percentage of axial strain compared to those specimen without rubber chips. As per Dallas N. Little [3], lime stabilization creates a number of important engineering properties in soils, including improved strength; improved resistance to fracture, fatigue, and permanent deformation; improved resilient properties; reduced swelling; and resistance to the damaging effects of moisture. The most substantial improvements in these properties are seen in moderately to highly plastic soils, such as heavy clays. Cement-modified soil is typically used to improve sub grade soils or to amend local aggregates for use as base in lieu of more costly transported aggregates. 


\section{EXPERIMENTAL INVESTIGATION}

\subsection{Materials}

\subsubsection{Soil}

Plastic, alluvial, red and black soils containing illitic or kaolinite and low proportions of expanding group of clay minerals, free from nodular lime or aggregates above $1 \mathrm{~mm}$ should be used for the manufacturing of roof tiles. But available clay is low to medium in plastic property, high sand contents and low in bonding. The engineering properties of clay samples collected from the sites for the investigations are given in table I and table II. Both the clay samples (good clay and problem clay) were collected from clay farms of Kundapur taluk, Udupi district.

Table 1: Geotechnical Properties of Good Clay

\begin{tabular}{|l|l|}
\hline Property & Values \\
\hline Specific gravity & 2.54 \\
\hline Liquid limit (\%) & 58 \\
\hline Plastic limit (\%) & 29.05 \\
\hline Plasticity index (\%) & 28.95 \\
\hline Shrinkage limit (\%) & 12.20 \\
\hline Shrinkage index (\%) & 45.80 \\
\hline Optimum moisture content (\%) & 16 \\
\hline Dry density (kN/m $\left.{ }^{3}\right)$ & 17.26 \\
\hline UCS( kN/m $\left.{ }^{2}\right)$ & 235.44 \\
\hline Gravel (\%) & 0 \\
\hline Sand (\%) & 25.7 \\
\hline Silt and Clay (\%) & 74.3 \\
\hline
\end{tabular}

Table 2: Geotechnical properties of problem clay

\begin{tabular}{|l|l|}
\hline Property & Values \\
\hline Specific gravity & 2.45 \\
\hline Liquid limit (\%) & 52 \\
\hline Plastic limit (\%) & 37.16 \\
\hline Plasticity index (\%) & 14.84 \\
\hline Shrinkage limit $(\%)$ & 13.91 \\
\hline Shrinkage index (\%) & 38.09 \\
\hline Optimum moisture content $(\%)$ & 18.8 \\
\hline Dry density(kN/m $\left.{ }^{3}\right)$ & 17.56 \\
\hline UCS $\left(\mathrm{kN} / \mathrm{m}^{2}\right)$ & 208.70 \\
\hline UCS @7days curing $\left(\mathrm{kN} / \mathrm{m}^{2}\right)$ & 219.54 \\
\hline Gravel $(\%)$ & 1.8 \\
\hline Sand $(\%)$ & 34.5 \\
\hline Silt and Clay $(\%)$ & 63.7 \\
\hline
\end{tabular}

\subsubsection{Crumb Rubber Powder (CRP)}

For improving the engineering properties of the problem clay, crumb rubber powder was chosen as an additive. Crumb rubber is a term usually applied to recycled rubber from automotive and truck scrap tires. During the recycling process steel and fluff is removed leaving tire rubber with a granular consistency. Continued processing with a granulator and/or cracker mill, possibly with the aid of mechanical means, reduces the size of the particles further. Now a day's Crumb rubber is often used as an additive in bituminous concrete mixes. Globally over 1 billion tyres are manufactured annually. The global rubber scrap figure stands at 10-16 million tons and almost $60 \%$ of this comes from tyres. Currently urban India is facing a massive rubber waste disposal. Rubber waste, when untreated, leads to various environmental concerns and wastage of natural resources which stresses the need to recycle rubber. Apart from environmental benefits recycling waste rubber also has tremendous potential of generating wealth. To address the above concerns CRP is used as an additive to improve the engineering properties of problem clay used in the local tile manufacturing industry, thus trying to reduce the impact of waste rubber in the environment. The CRP which is used in the study are of $1.18 \mathrm{~mm}$ down size (IS sieve) (Figure 1). In the present investigation, CRP is used as an additive in the present investigation to get desired engineering properties in the available problem clay and also to make the roofing tiles light weight.

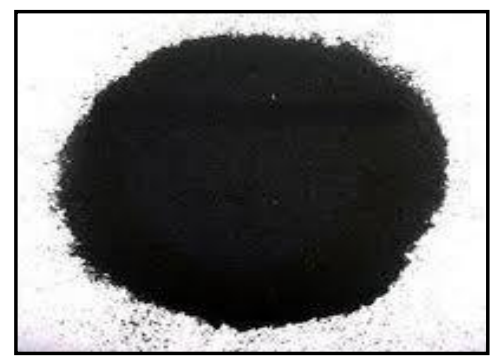

Figure 1: Crumb Rubber Powder

\subsubsection{Cement and Lime}

Cement used for the experimental investigation was 43 grade, Ordinary Portland Cement (RAMCO) and hydrated lime (BIRLA WHITE) has been used in small percentages $(1 \%, 3 \%$ and $5 \%)$.

\section{RESULTS AND DISCUSSIONS}

The experimental investigation was carried out in two phases. In the first phase, study was done on the problem clay with varied percentages $(5 \%, 10 \%, 15 \%, 20 \%$ and $25 \%)$ of CRP. The samples (untreated \& treated) were tested for specific gravity (IS: 2720 part-3, 1980) [4], grain size analysis (IS: 2720 part-4, 1985) [5] and Atterberg limits (IS: 2720 part$5 \& 6,1985)$ [6] [7]. The standard proctor compaction tests (IS: 2720 part 7-1980) [8] were performed on untreated and treated samples to get the water content-dry density relation. The standard proctor compaction results were used to prepare test samples for the unconfined compressive strength (IS: 2720 part 10-1973) [9]. The test samples were carefully prepared by maintaining uniformity in density, moisture content and curing time in order to ensure a fair assessment of the effects of the admixture on the geotechnical properties. The testing for stabilized soils was being done by giving a specific period for enhancing the stabilization reaction, which is literally termed as curing period. This investigation was carried out to study the variation of the properties of the problem clay after blending with CRP. Based on the results problem clay $+5 \%$ CRP was chosen as the optimum blended 
mix. For this optimum blended mix (5\% CRP + problem clay) with varying proportions of cement / lime $(1 \%, 3 \%$, and $5 \%)$ all the above mentioned geotechnical properties have been carried out.

The tests revealed that $5 \% \mathrm{CRP}+$ problem clay gives better results and is chosen as optimum blended mix. And in the second phase, the optimum blended mix (5\% CRP + problem clay) is tested with mixing cement / lime in varied percentages to get desired strength properties. Table III presents the

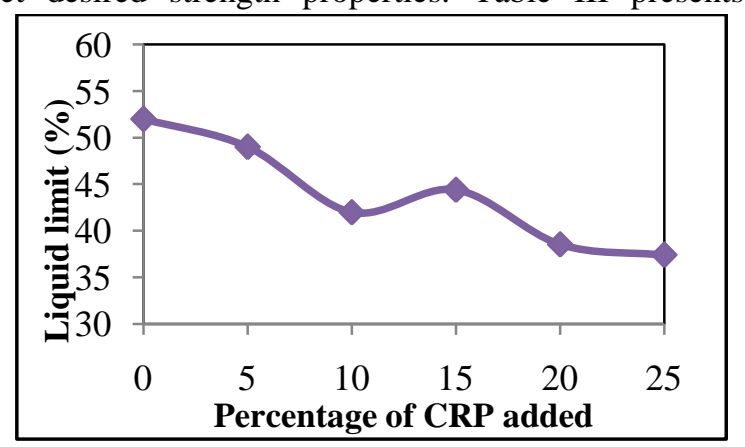

Figure 2: Variation of Liquid Limit with Percentage of CRP Added

Table 3: Geotechnical Properties of CRP Stabilized Soil

\begin{tabular}{|c|c|c|c|c|c|c|c|c|c|}
\hline Sample & $\begin{array}{c}\text { Liquid } \\
\text { limit } \\
(\%)\end{array}$ & $\begin{array}{c}\text { Plastic } \\
\text { limit } \\
(\%)\end{array}$ & $\begin{array}{c}\text { Plasticity } \\
\text { index } \\
(\%)\end{array}$ & $\begin{array}{c}\text { Shrinkage } \\
\text { limit } \\
(\%)\end{array}$ & $\begin{array}{c}\text { Optimum } \\
\text { moisture } \\
\text { content } \\
(\%)\end{array}$ & $\begin{array}{c}\text { Dry } \\
\text { density } \\
\left(\mathrm{kN} / \mathrm{m}^{3}\right)\end{array}$ & $\begin{array}{c}\text { UCS } \\
\left(\mathrm{kN} / \mathrm{m}^{2}\right)\end{array}$ & $\begin{array}{c}\text { UCS } \\
7 \text { days } \\
\text { curing } \\
\left(\mathrm{kN} / \mathrm{m}^{2}\right)\end{array}$ & $\begin{array}{c}\text { UCS } \\
\text { after kiln } \\
\text { Burning } \\
\left(\mathrm{kN} / \mathrm{m}^{2}\right)\end{array}$ \\
\hline Good clay & 58.00 & 29.05 & 28.95 & 12.20 & 16.00 & 17.27 & 165.50 & - & - \\
\hline Problem clay & 52.00 & 37.16 & 14.84 & 13.91 & 18.80 & 17.56 & 150.75 & 189.41 & 2685.16 \\
\hline $\begin{array}{c}5 \% \text { CRP+Problem } \\
\text { clay }\end{array}$ & 49.00 & 23.74 & 25.26 & 11.06 & 16.20 & 16.97 & 234.81 & 252.00 & 3454.52 \\
\hline $\begin{array}{c}10 \% \text { CRP+Problem } \\
\text { clay }\end{array}$ & 42.00 & 24.65 & 17.35 & 11.46 & 17.60 & 16.14 & 96.44 & 195.98 & 2590.72 \\
\hline $\begin{array}{c}15 \% \text { CRP+Problem } \\
\text { clay }\end{array}$ & 44.40 & 26.38 & 18.02 & 11.48 & 17.50 & 15.50 & 65.48 & 141.62 & 2055.24 \\
\hline $\begin{array}{c}20 \% \text { CRP+Problem } \\
\text { clay }\end{array}$ & 38.55 & 24.13 & 14.42 & 11.81 & 17.00 & 15.45 & 56.42 & 74.76 & - \\
\hline $\begin{array}{c}25 \% \text { CRP+Problem } \\
\text { clay }\end{array}$ & 37.40 & 23.03 & 14.37 & 12.50 & 16.00 & 15.01 & 44.32 & 66.70 & - \\
\hline
\end{tabular}

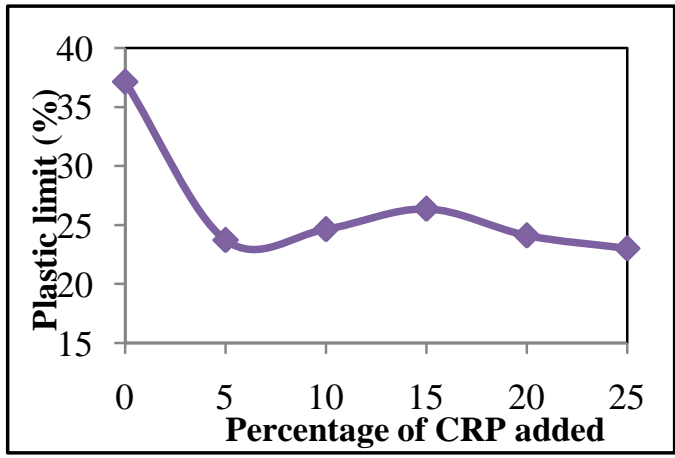

Figure 3: Variation of Plastic Limit with Percentage of CRP Added experiment results with respect to CRP addition to problem clay. The variation of geotechnical properties with percentage of CRP added is presented in Figure 2 -7. 


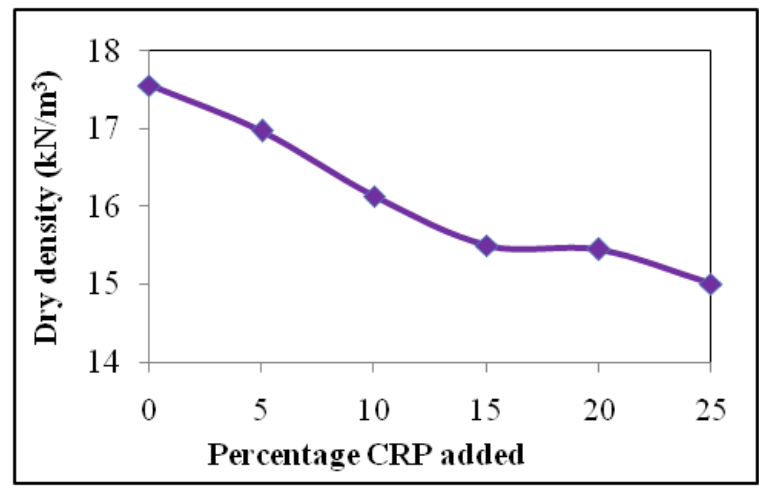

Figure 5: Variation of Dry Density with Percentage of CRP Added

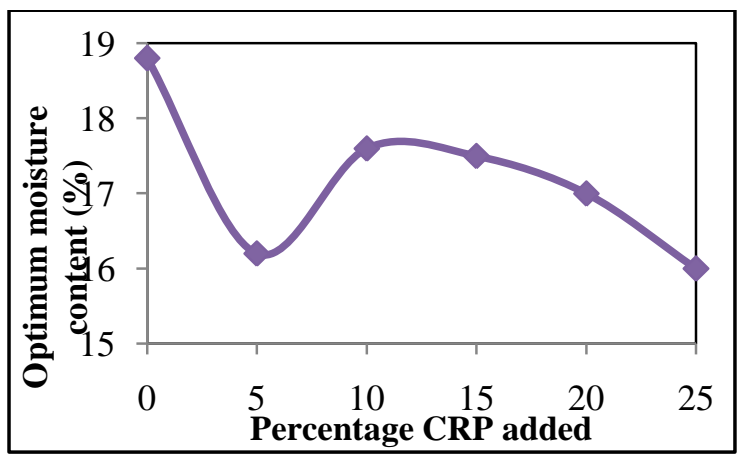

Figure 6: Variation of OMC for CRP-Problem Clay

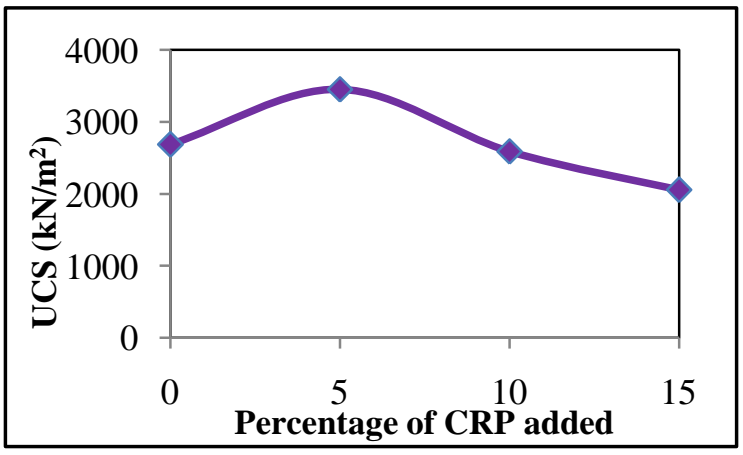

Figure 7: Variations of UCS (after kiln burning) for CRPProblem clay

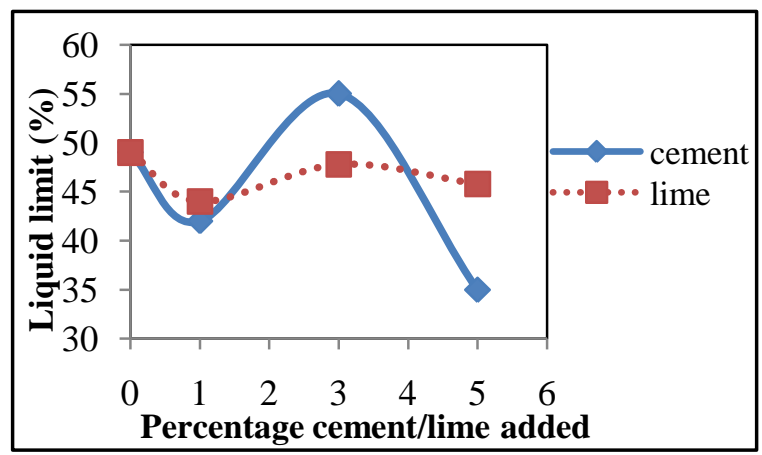

Figure 8: Variation of Liquid Limit with Percentage of Cement/Lime Added

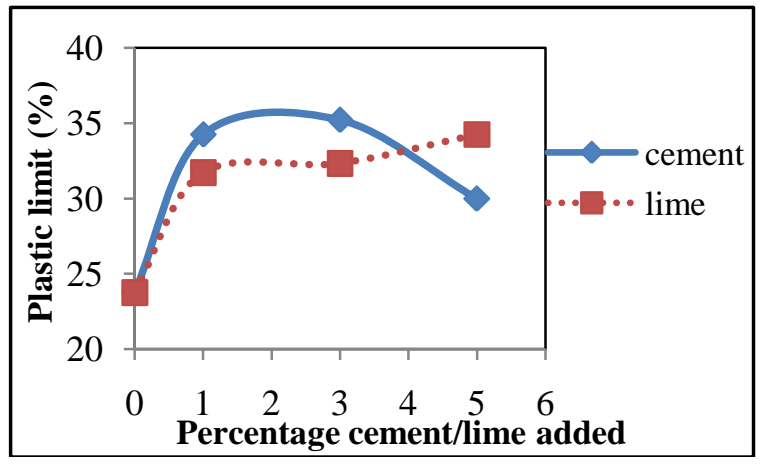

Figure 9: Variation of Plastic Limit with Percentage of Cement/Lime Added

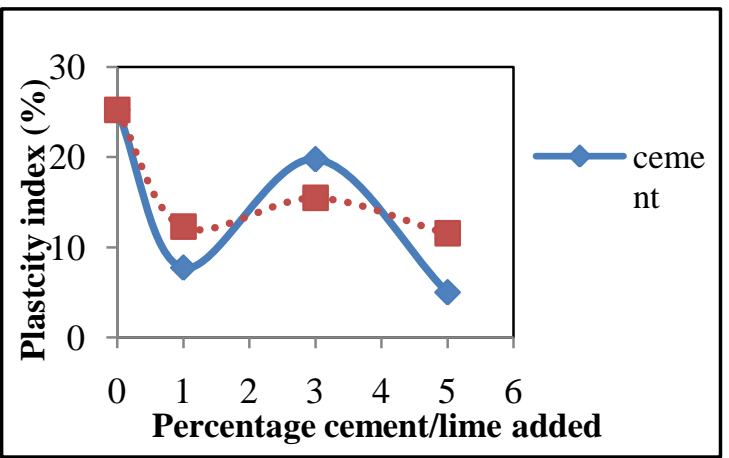

Figure 10: Variation of Plasticity Index with Percentage of Cement/Lime Added

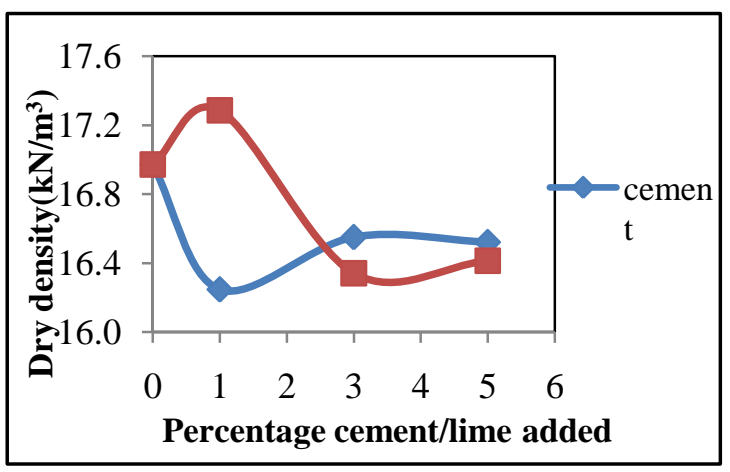

Figure 11: Variation of Dry Density with Percentage of Cement/Lime Added

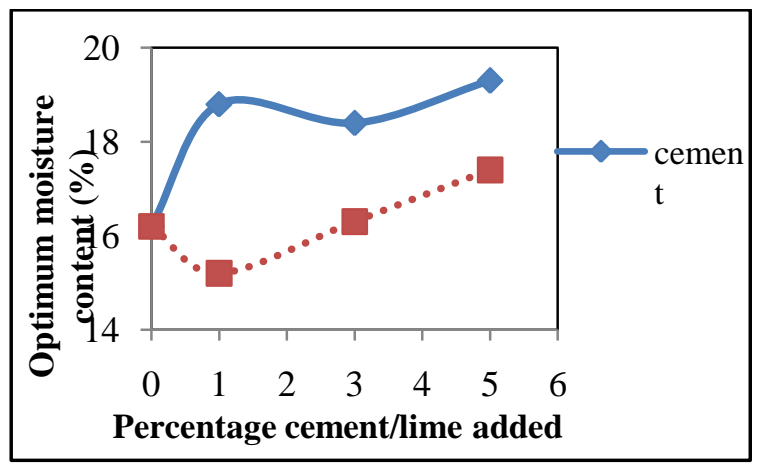

Figure 12: Variation of OMC with Percentage of Cement/Lime Added 
From Figure 5, it is clearly seen that, 5\% CRP mix has the maximum dry density compared to other mixes though less than the problem clay but the optimum moisture content (Figure 6) for problem clay is very high compared to 5\% CRP sample, thus 5\% CRP sample has the maximum strength compared to problem clay and other CRP mixed samples. From Table III, it is clear that, 5\% CRP-problem clay blended mix shows maximum unconfined compressive strength compared to all other CRP-problem mixes. The figure 7 reveals that 5\% CRP blended mix (after kiln burning) shows maximum unconfined compressive strength compared to all other CRP-problem mixes. Hence 5\% CRP is selected as optimum mix for improving the geotechnical properties of problem clay. In the second phase of the investigation the selected optimum mix (5\% CRP) is used along with cement/lime $(1 \%, 3 \%$ and $5 \%)$ to study the behaviour of CRP blended problem clay after cement/lime stabilization.

Table 4: Geotechnical Properties of (5\% crp + problem clay) + Cement

\begin{tabular}{|c|c|c|c|c|c|c|c|c|c|}
\hline Sample & $\begin{array}{c}\text { Liquid } \\
\text { limit } \\
(\%)\end{array}$ & $\begin{array}{c}\text { Plastic } \\
\text { limit } \\
(\%)\end{array}$ & $\begin{array}{l}\text { Plasticity } \\
\text { index }(\%)\end{array}$ & $\begin{array}{l}\text { Shrinkage } \\
\text { limit } \quad(\%)\end{array}$ & $\begin{array}{l}\text { Optimum } \\
\text { moisture } \\
\text { content } \\
(\%)\end{array}$ & $\begin{array}{c}\text { Dry } \\
\text { density } \\
\left(\mathrm{kN} / \mathrm{m}^{3}\right)\end{array}$ & $\begin{array}{c}\mathrm{UCS} \\
\left(\mathrm{kN} / \mathrm{m}^{2}\right)\end{array}$ & $\begin{array}{c}\text { UCS } \\
\text { (after } 7 \\
\text { days } \\
\text { curing) } \\
\left(\mathrm{kN} / \mathrm{m}^{2}\right)\end{array}$ & $\begin{array}{c}\text { UCS } \\
\text { (after } \\
\text { kiln } \\
\text { burning) } \\
\left(\mathrm{kN} / \mathrm{m}^{2}\right)\end{array}$ \\
\hline Good clay & 58.00 & 29.05 & 28.95 & 12.20 & 16.00 & 17.27 & 234.44 & - & - \\
\hline Problem clay & 52.00 & 37.16 & 14.84 & 13.91 & 18.80 & 17.56 & 208.70 & 219.54 & 2685.16 \\
\hline $\begin{array}{c}5 \% \text { CRP + Problem } \\
\text { clay }\end{array}$ & 49.00 & 23.74 & 25.26 & 11.06 & 16.20 & 16.97 & 329.70 & 361.24 & 2754.52 \\
\hline $\begin{array}{c}5 \% \text { CRP }+1 \% \\
\text { Cement }\end{array}$ & 42.00 & 34.25 & 7.75 & 14.46 & 18.80 & 16.25 & 170.36 & 266.95 & 1145.99 \\
\hline $\begin{array}{c}5 \% \text { CRP + 3\% } \\
\text { Cement }\end{array}$ & 55.00 & 35.21 & 19.79 & 22.96 & 18.40 & 16.55 & 445.71 & 339.72 & 1358.22 \\
\hline $\begin{array}{c}5 \% \text { CRP }+5 \% \\
\text { Cement }\end{array}$ & 35.00 & 29.99 & 5.01 & 28.98 & 19.30 & 16.52 & 366.16 & 391.63 & 1593.28 \\
\hline
\end{tabular}

Table 5: Geotechnical Properties of (5\% CRP + problem clay) + Lime

\begin{tabular}{|c|c|c|c|c|c|c|c|c|c|}
\hline & $\begin{array}{c}\text { Liquid } \\
\text { limit } \\
(\%)\end{array}$ & $\begin{array}{c}\text { Plastic } \\
\text { limit } \\
(\%)\end{array}$ & $\begin{array}{c}\text { Plasticity } \\
\text { index }(\%)\end{array}$ & $\begin{array}{c}\text { Shrinkage } \\
\text { limit }(\%)\end{array}$ & $\begin{array}{c}\text { Optimum } \\
\text { moisture } \\
\text { content } \\
(\%)\end{array}$ & $\begin{array}{c}\text { Dry } \\
\text { density } \\
\left(\mathrm{kN} / \mathrm{m}^{3}\right)\end{array}$ & $\begin{array}{c}\text { UCS } \\
\left(\mathrm{kN} / \mathrm{m}^{2}\right)\end{array}$ & $\begin{array}{c}\text { UCS } \\
(\text { after 7 } \\
\text { days } \\
\text { curing) } \\
\left(\mathrm{kN} / \mathrm{m}^{2}\right)\end{array}$ & $\begin{array}{c}\text { UCS } \\
(\text { after } \\
\text { kiln } \\
\text { burning }) \\
\left(\mathrm{kN} / \mathrm{m}^{2}\right)\end{array}$ \\
\hline Good clay & 58 & 29.05 & 28.95 & 12.20 & 16.00 & 17.27 & 234.44 & - & - \\
\hline Problem clay & 52 & 37.16 & 14.84 & 13.91 & 18.80 & 17.56 & 208.70 & 219.54 & 2685.16 \\
\hline $\begin{array}{c}5 \% \text { CRP + Problem } \\
\text { clay }\end{array}$ & 49 & 23.74 & 25.26 & 11.06 & 16.20 & 16.97 & 329.70 & 361.24 & 3454.521 \\
\hline $5 \%$ CRP + 1\% lime & 44 & 31.71 & 12.29 & 38.62 & 15.20 & 17.29 & 363.26 & 529.68 & 934.66 \\
\hline $5 \%$ CRP + 3\% lime & 47.8 & 32.32 & 15.48 & 33.09 & 16.30 & 16.34 & 382.72 & 936.84 & 1052.32 \\
\hline $5 \%$ CRP + 5\% lime & 45.8 & 34.25 & 11.55 & 27.88 & 17.40 & 16.41 & 389.72 & 1030.30 & 1191.41 \\
\hline
\end{tabular}

Table IV and V presents the experimental results of $5 \%$ CRP + cement $(1 \%, 3 \%$ and $5 \%)$ and 5\% CRP + lime (1\%, $3 \%$ and $5 \%$ ) respectively. The variation of geotechnical properties with the increasing percentage of cement and lime is shown in Figure 8-12. With the addition of cement/lime a further improvement in the geotechnical properties were observed.
There was reduction in liquid limit when $5 \%$ cement/lime was added. There was decrease in plasticity index when $3 \%$ cement/lime. There was decrease in maximum dry density as the percentage of cement and lime was increased from $1 \%$ to $5 \%$. There was increase in optimum moisture content as the percentage of cement and lime was increased from $1 \%$ to $5 \%$. 


\section{CONCLUSIONS}

With the increasing problems of local tile manufacturers to improve the engineering behaviour of problem clay used in manufacture of Mangalore tiles, CRP, a waste from tyre industry was used as an additive for the stabilization. The problem clay was blended with varying percentage of CRP $(5 \%, 10 \%, 15 \%, 20 \% \& 25 \%)$ to study the improvement in engineering properties of problem clay.

The following conclusions are drawn from the present investigation:

The percentage reduction in liquid limit and plasticity index was about $6 \% \& 58 \%$ when 5\% CRP was added. There was decrease in maximum dry density as the percentage of CRP was increased from $5 \%$ to $25 \%\left(1.73 \mathrm{kN} / \mathrm{m}^{3}\right.$ to $\left.1.53 \mathrm{kN} / \mathrm{m}^{3}\right)$. There was decrease in optimum moisture content up to $10 \%$ addition of CRP (from $16.2 \%$ to $17.6 \%$ ) and further addition of CRP increases the optimum moisture content. Improvement in the unconfined compressive strength (40\%) was observed for an addition of 5\% CRP.

The percentage reduction in liquid limit was about $28 \%$ when $5 \%$ cement and about $6.5 \%$ reduction when $5 \%$ lime was added to $5 \% \mathrm{CRP}+$ problem clay mix. There was decrease in plasticity index of about $22 \%$ when $3 \%$ cement was added and $38 \%$ reduction when for $3 \%$ addition in lime and then there was decrease. There was decrease in maximum dry density as the percentage of cement and lime was increased from $1 \%$ to $5 \%\left(1.73 \mathrm{kN} / \mathrm{m}^{3}\right.$ to $\left.1.68 \mathrm{kN} / \mathrm{m}^{3}\right)$ and $\left(1.73 \mathrm{kN} / \mathrm{m}^{3}\right.$ to $\left.1.67 \mathrm{kN} / \mathrm{m}^{3}\right)$, but $1 \%$ addition of lime has $\max$ dry density of $1.76 \mathrm{kN} / \mathrm{m}^{3}$. There was increase in optimum moisture content of about $16 \%$ addition of cement (from $16.2 \%$ to $19.3 \%$ ) and increase of about $7 \%$ as lime proportion increased (from $16.2 \%$ to $17.4 \%$ ).

\section{REFERENCES}

[1] Alaa Ashmawy, Rory McDonald, Delfin Carreon and Fikret Atalay, "Stabilization of marginal soils using recycled materials", Florida department of transportation, 2006.

[2] Dallas N Little, Eric H. Males, Jan R Prusinski and Barry Stewart, "Cementitious Stabilization", Transportation in the new millennium, A2J01, Louisiana state university.

[3] Meei-Hoan Ho and Chee-Ming Chan, "The Potential of Using Rubber chips as a Soft Clay Stabilize Enhancing Agent", Modern Applied Science, Vol. 4, No.10, 2010.

[4] IS: 2720 (Part 3/Section 1)-1980, (Reaffirmed 2002) "Methods of Test for Soil: Determination of Specific Gravity." Bureau of Indian Standards.

[5] IS: 2720 (Part 4)-1985, (Reaffirmed 2006) "Methods of Test for Soil: Grain Size Analysis." Bureau of Indian Standards.

[6] IS: 2720 (Part 5)-1985, (Reaffirmed 2006) "Methods of Test for Soil: Determination of Liquid and Plastic limits." Bureau of Indian Standards.

[7] IS: 2720 (Part 6)-1972, (Reaffirmed 2001) "Methods of Test for Soil: Determination of Shrinkage Factors." Bureau of Indian Standards.

[8] IS: 2720 (Part 7)-1980, (Reaffirmed 2002) "Methods of Test for Soil: Determination of Water Content - Dry density Relation Using Light Compaction." Bureau of Indian Standards.

[9] IS: 2720 (Part 10)-1973, "Methods of Test for Soil: Determination of Unconfined Compressive Strength.” Bureau of Indian Standards.

[10] http:// en.wikipedia.org

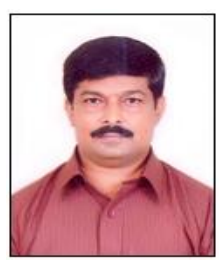

Dr.Purushotham G. Sarvade born in Shimoga district, Karnataka, India on 15/05/1965. He obtained his B.E degree in Civil Engineering at M.I.T, Manipal under Mangalore University in the year 1986. He received his M.Tech degree at NITK, Surathkal in Geotechnical Engineering under Mangalore University in the year 1993. Further, he obtained his Ph.D. from NITK, Surathkal in the year 2011. He is presently working as Associate Professor in the department of Civil Engineering, Manipal Institute of Technology, Manipal University, Manipal. He has over 24 years of teaching experience. He has to his credit about 12 technical papers in various National and International journals and conferences. (E-mail:pgsarvade@gmail.com) 